TILTAI, 2014, 4, 143-159, ISSN 1392-3137 (Print), ISSN 2351-6569 (Online)

\title{
ON THE DISCOURCE OF SOCIAL WORK PROFESSIONALISATION
}

\author{
Elvyra Acienė, Sonata Mačiulskytė \\ Klaipèda University
}

\begin{abstract}
The paper presents the discourse of the social work professionalization from the viewpoints of practice, research, academic activity, and professional identity, by revealing the expression of social worker competencies in the changing society. By means of evaluating the 20-year-experience of social worker training in Lithuania, the authors reveal the identity of social work at two levels: professional (academisation and practice) and legal (profession and study status). For the purpose, a novel approach to the formation of the social work theory, study methods, and the education of intercultural communication and lifelong learning is employed.

KEY WORDS: professionalization, social work identity, problem based learning, intercultural communication, lifelong learning.
\end{abstract}

\section{Anotacija}

Šiame straipsnyje pristatomas socialinio darbo profesionalizacijos diskursas praktikos, mokslo, akademinès veiklos ir profesijos identiteto aspektais, atskleidžiant socialinio darbuotojo kompetencijų raišką besikeičiančioje visuomenèje. Autorès, ịvertindamos socialinio darbuotojo rengimo Lietuvoje dvidešimtmetę patirtį, socialinio darbo identitetą atskleidžia dviem lygmenimis: profesionaliu (akademizacija ir praktika) ir teisiniu (profesijos ir studijų statusas). Pasitelkiamas naujas požiūris ị socialinio darbo teorijos formavimąsi, studijų metodus, tarpkultūrinès komunikacijos ir mokymosi visą gyvenimą ugdymą.

PAGRINDINIAI ŽODŽIAI: profesionalizacija, socialinio darbo identitetas, probleminis mokymas, tarpkultūrinè komunikacija, mokymasis visą gyvenimą.

DOI: http://dx.doi.org/10.15181/tbb.v68i4.956

\section{Introduction}

In Lithuania social worker training has been realized for only two decades. After declaring the Independence in a complicated socioeconomical situation the country has chosen a strategy - to use the ways of solving social problems that have been used in recent decades in many modern welfare states, i.e. to create the stable system of social security (social welfare) and professionalize rendering social services, "amortizing" the impact of social problems and creating the models of the prevention of social problems. Estimating the fact that professional social work in other countries could perform these important functions, the need of new professionals - social workers - has become clear in Lithuania. Professional social workers are the ones who can change the relation between a person and his/her 
environment through social work interventions ensuring people rights (Vareikytė, 2010, p. 33-34).

R. Laužackas (2008) assumes that all professions typically involve two elements, respectively reflecting two sides of the profession: objective and subjective. The objective side includes everything what is related to material working conditions and circumstances. The subjective side mirrors a person's knowledge, skills, attitudes and a person's efforts to implement the required goals of the profession. The basic contradiction of the profession is of particular importance as it signifies a constant contradiction between the objective (performance characteristics and requirements) and subjective sides of the profession. This contradiction is largely solved by the person's leaning processes. By upgrading his / her qualification, a person keeps in tune to the changing working conditions and requirements. Therefore, the qualification growth is the primary condition for performing more and more complex activities. In this respect, profession is interrelated with education and training (Ibid., p. 13).

Thus the system of higher education institution has faced the challenge - to search for the model how to train qualified social workers who would meet the demands of changing society oriented towards citizens' activity. Therefore, during the first decade the concept of social work was most often related to the perception of social work as a profession and was treated rather as a professional activity than science. Only in 2009, according to the resolution of the Government of the Republic of Lithuania No. 1749 social work became an independent study field. However, social work is still not treated as a science field. Scientific definition of social work has not been consolidated yet either. According to A. Bagdonas (2001), every trend of social work, theoretical paradigm, perspective has its concept and definition. General social work theory still is in the stage of formation, because what we call social work theory at the moment is the application of the knowledge of related sciences (psychology, sociology, philosophy, etc.) to analyze social work objects.

At the same time social work researchers more often speak about the methods of social work science emphasizing the opportunity to reveal social reality and intervention into positive change of social reality. However, an increasing number of social work masters strive for $\mathrm{PhD}$ in social work abroad (at the moment in Lithuania there are already 10 doctors in social work who have prepared and defended doctoral theses in foreign universities). In recent years it is becoming more and more important to search for the scientific substantiation of social problems, interpreting the opportunities of problem solving in the context of the achievements of modern science. Scientifically interpreting social reality social work becomes not 
only a practical activity but also a science. Social work research is more and more often perceived as a process that reveals scientific-applied space of social work.

When we talk about social work reality in the process of research practice it is based on reflectivity, and the results of empirical research may cover a wide range of social phenomena that is being converted into the construction of new knowledge, opportunities of the change of social reality in the context of solving particular social problems. At the same time life-long learning skills that are very important for a social worker because his/her activity every time takes place in new and undefined situations are being formed.

Social work research develops intensively in Lithuania. So, rephrasing L. Epstein (1999), what can one say about the development of social work in Lithuania that has not already been said? L. Epstein $(1999$, p. 7) argues that something much more meaningful needs to be understood about social work because it is a large and impressive social institution that has spread its influence widely, but still everybody understands it vaguely.

According to foreign authors, the question of social work as a profession has not been answered even after a hundred years of discussions (if we assume that the starting point is the question "Is social work a profession?", raised by Flexner in 1915). An extremely intense debate concerning the issues of social work professionalization took place in the West in the $2^{\text {nd }}$ half of the $20^{\text {th }}$ century $(50 \mathrm{~s}-70 \mathrm{~s}$ ) (Greenwood, 1957; Bartlett, 1970). J. Baird (1972) was the one who actively participated in the debate: he formulated the concept of social work and named the choice of occupational criteria as the key measure when making a decision to name this activity either a profession or a semi-profession. Nevertheless, even in the turn of the centuries, L. C. Johnson (2001) wrote about the ongoing debate on social work as a profession subject, naming the absence of a "clear and comprehensive definition" as the main reason of this debate (cited in Kavaliauskiené, 2005, p. 231).

The study of the issue of professionalization in social work in Lithuania is fragmentary; usually the aspect of social work identity as a profession is addressed. In 2003, in her monograph "Socialization and Child Welfare", G. Kvieskiene discusses the issue of social education (work) development as a profession in the context of child welfare. I. Dirgèlienè (2008), V. Kavaliauskienè (2010) address the professionalization aspect by exploring the opportunities of reflection in the social worker's professional activity.

Over 20 years of social work development in Lithuania, many works have been published addressing various issues of social work. However, only two comprehensive works have been published in the area of social work: in her doctoral 
dissertation, R. Jurkuvienè (2003) explores social work as innovation; R. Čepukas (2005) touches upon the topic of social work while exploring the non-university training tendencies of social pedagogues in his doctoral dissertation. There is also a need for a comprehensive conceptual analysis of the issue of professional social work development.

The analysis of social work professionalization gains significance taking into consideration the fact that from the very beginning, when forming its professional identity, social work had to compete with another social profession - social education, which started its professional identity development in the final years of the Soviet Union existence (Leliūgienè, 2003), and which initially had much stronger positions and more favourable conditions for development in post-communist Lithuania. Nevertheless, rapid development of social work as a profession was observed during the last decade, meanwhile, as far as social education is concerned, its influence reduced and development slowed down.

A number of Lithuanian authors have analysed the issues discussed in this article. The complexity of social work as a profession and the variety of methods were disclosed by L. Gvaldaitė and B. Švedaitè (2005). A. Bagdonas (2001) highlighted the interaction model of social work process as the main factor of the social worker's performance complexity, and actualized the problem of quality of social work practice organization. P. Jucevičiene (2001) revealed the need for reflective practice in developing the relationship between theory and practice in the process of social workers' training and professional activities in order to empower clients to act individually. The issues of development of the relationship between theory and practice in the process of social workers' training were analysed by V. Ivanauskienè and N. Liobikienè (2005); in addition, N. Liobikienè (2006) highlighted the significance of reflected professional experience in a crisis intervention situation, actualizing the links between personal, professional and social experience. I. Dirgèlienè and A. Kiaunytė $(2005,2006)$ presented the reflective practice and its organization system in training of social workers. V. Kavaliauskienè $(2005,2010)$ analysed the issues of social worker's professional mission, professional competence structure, complexity of social work profession.

The aim of this article is to reveal social work in a changing society.

The object is social work professionalization.

The authors of this article apply literature review and document analysis methods to reveal the object mentioned above. 


\section{Research of social problems as precondition to social work profesionalization}

R. Vaičekauskaite and E. Acienè (2007) used to write that "theory and methods are the tools of the discipline, therefore, in study process it is important for students to master the basics and methods of certain science, in this case of social work. The research methods should respond to the opportunities to consistently solve set objectives. Students choose research methods that they have mastered the best in study process. The application of the method is inseparable from student's research object (i.e., social work), therefore, the methods (usually sociological) have a creative aspect responding to the peculiarities of social work. The interpretation of scientific research is one of the most difficult stages of work. Only consistently and systematically preparing the work a student becomes a mature analytical researcher. $<\ldots>$ Social research is a systemic observation of social life in order to understand and evaluate life situations. Writing scientific works as an inseparable part of training social workers guides a student into the space of social work reality and through growing scientific competence strengthens his/her professional competences".

The common declaration of the International Association of Schools of Social Work (IASSW) and the International Federation of Social Workers (IFSW) states that social work methodology refers to the system of knowledge based on evidence obtained by the research of practical activity and evaluation also including narrower knowledge characteristic to certain contexts. Social work theory takes the complexity of people's interaction with their environment into account and acknowledges people's ability both to surrender to the influence and change the influence of various factors. Professional social work in analyzing complex situations and encouraging individual, organizational, social and cultural changes apply the theories of the development of human behaviour and social systems (Kozlovas, 2004, p. 72).

Application and permanent practice of certain theory and research methods promotes the construction, formation, development and consolidation of professional identity via teaching / learning process. Furthermore, professional identity is constructed, on the one hand, by occupying a clearly identifiable niche of professional activity in the professional field, creating unique methods of work, clearly identifying the objects of professional activity; on the other hand, this process is promoted by applying carefully selected study methods. The authors present one of the methods to help strengthen the analytical and life-long learning skills. 
A problem-based study method can be acknowledged as one of the methods strengthening the professional identity of social work. That method highlights the essence of social work content and social worker's competences in interdisciplinary context.

It is accepted to state that problem-based teaching in the study process of higher education was used for the first time in medical study programmes at McMaster University (Canada), although the origins of problem-based learning may be found already earlier in the USA (Mažeikienè, Lenkauskaite, 2011, p. 7). This observation is interesting for social work studies because Dewey (Ibid) defined problem solving as a way to understand the community and belong to it. There is no doubt that in the process of the globalization of society the contexts of the perception of a problem have changed, the content of the paradigm of problem-based learning has changed as well. Problem-based learning in many universities is realized together with a traditional study system. Problem-based teaching permits to have a new look to the relations between teaching and learning, influences study quality, requires new culture of studies. Therefore, "maintaining traditionalism and modernism is becoming one of the objectives of the study system that is getting more and more modern, that permits to predict the changes in teaching and learning culture" (Šveikauskas et al., 2008, p. 85-94). According to L. Kirikova et al. (2013, p. 24-25), "teachers in a contemporary higher education institution, when a usual teaching and lecturing paradigm is being replaced by learning paradigm, are considered as the organizers of the process, creators of educational environment. Problem-based learning is such a study strategy, the basis of which is the interaction between students and teachers, characterized by systemic autonomous cognitive activity, learning new knowledge and ways of activity in solving practical problems".

Lithuanian University of Health Sciences started to apply problem-based learning in study process already in the academic year 2007/2008 and treats this learning not only as a method but also as a learning strategy; the authors of this article also tend to treat problem-based learning as a learning strategy. The L. Kirikova et al. (Ibid) research results reveal teachers' attitude towards the advantages of problem-based learning: students gain deeper knowledge, students' self-directed learning is stimulated, they gain analyzing skills, the integration of many disciplines manifests itself, they develop life-long learning skills, use more various sources of information, students' discussions are stimulated, they gain communication skills, better psychological atmosphere is formed, students get bigger motivation, they work more actively, learn how to plan time, develop management skills.

In the project of the Description of the Field of Study of Social Work (2012) it is written that "social work covers a wide scope of interdisciplinary theoretical 
and practical knowledge, therefore, in defining study content it should be referred to thorough information, acquired referring to the experience of other disciplines, discussing with social partners, referring to the examples of foreign good experience, etc. The specificity of the profile of the study programme is formed by historical, political, economical, social, cultural, demographical and other factors. New knowledge, technologies and ideas that may have influence on the development of contemporary and future social work studies as science and practice also should be the part of the strategy of modelling the content of the programme".

Here we present several most characteristic definitions of the strategy (method) of problem-based learning.

"Problem-based learning is learning based on specific learning technique, which has many individual components that students face working in small groups and analyzing selected problems. Every component of problem-based learning is important in order to achieve maximal result from this learning" (Šveikauskas, 2007, p. 4).

Table 1. Differences of traditional and problem-based learning

\begin{tabular}{|c|c|}
\hline Traditional teaching & Problem-based learning \\
\hline $\begin{array}{l}\text { Theoretical contexts little related } \\
\text { to real life are analyzed }\end{array}$ & Students learn to adjust knowledge to real social life \\
\hline Students - users of information & Students - producers of information \\
\hline Teacher asks, students answer & Students pose questions and search for answers \\
\hline Students study according to sources indicated to them & Students study the sources discovered by themselves \\
\hline Students passively listens to a teacher in a big group & $\begin{array}{l}\text { Students work in a small group solving a problem } \\
\text { that has been formulated together }\end{array}$ \\
\hline Students learn from a teacher & Students learn from each other \\
\hline Students learn competing with each other & Students learn in collaboration \\
\hline Students learn in order to pass examination & $\begin{array}{l}\text { Students learn in order to turn comprehended } \\
\text { knowledge into knowing }\end{array}$ \\
\hline Students learn the facts as knowledge & $\begin{array}{c}\text { Students see practical application and suitability } \\
\text { of what they have learned }\end{array}$ \\
\hline Students usually use textbooks & Students refer to various sources \\
\hline
\end{tabular}

Source: composed according to Azer (2008) (cited in Mažeikienė, Lenkauskaitè, 2011)

"It is a method stimulating self-directed learning and giving students practical skills to solve intricate situations and to identify the gaps in their knowledge them- 
selves in the context of a particular problem" (Internet access: http://radiologija.lt/ Mokslai/Probleminis-mokymasis-KMU).

"Problem-based learning is a pedagogical strategy for posing significant, contextualized, real world situations, and providing resources, guidance, and instruction to learners as they develop content knowledge and problem-solving skills (Mayo, Donnelly et al., 1993)" (Ibid).

According to Savery (2006) (cited in Mažeikienè, Lenkauskaite, 2011) "problem-based learning is a learner-centred approach that empowers learners to conduct research, integrate theory and practice, and apply knowledge and skills to develop a viable solution to a defined problem"; Torp, Sage (2002) (Ibid) defined problem-based learning as focused, experiential learning organized around the investigation and resolution of messy, real-world problems. The authors evaluate students as problem solvers who have motivation, to whom self-directed learning reflecting in a group gives possibility to find a suitable solution of the problem. The definition by Barrows and Tamblyn (2008) (cited in Targamadzè, Gražienè, 2012) that "problem based learning is the learning that results from the process of working toward the understanding or resolution of a problem" is considered as classical.

These definitions presuppose the possibility to apply problem-based learning in the study process of social work.

V. Šveikauskas and L. Kirikova (2007) present the main aims of problembased learning, generalizing theoretical and practical insights into problem-based learning by Savin-Baden, Major (2004), Barrows (1985), Silen, Uhlim (2004) as the result of problem-based learning activity tested by various scientists. Main aims of problem-based learning:

1. Gaining knowledge.

2. Development of problem solving skills using the gained knowledge.

3. Development of self-directed learning to make it the way of life.

4. Stimulation of critical thinking.

5. Development of sensitivity towards all needs (both medical and psychosocial) of patients.

6. Encouragement to apply the possessed information to knowledge in order to solve the main problems of patients.

7. To transfer to students (available learning methods, perception that their studies are important; methods which are suitable for individual learning).

Philosophical aspects of problem-based learning. The aforementioned aims may be easily converted in study programmes of social work. Philosophical principles of problem-based learning are based on the methodological 
approaches of humanism, existentialism, pragmatism, progressivism, hermeneutics and social constructivism and directly correlate with the aims of problem-based learning. It is especially important in social sciences where every problem is solved in the interaction with social environment that is constantly changing both in social, economical and political contexts. Humanistic principles are followed by many scientists of Lithuania that investigate the strategies of vocational training. According White book (2005), one of four principles of Lithuanian education is humanistic principle that substantiates the necessity to implement person's value, respect person's individuality, freedom of everyone choice, humanistic relationships based on common human values. The authors who analyze the method (strategy) of problem-based learning mention the trend of progressivism in philosophy of education a little more rarely. However, when applying the method (strategy) of problem-based learning in social work studies we would like to focus on the insights by R. Laužackas (2008, p. 60). "Progressivism in a given situation of solving a social problem emphasizes the aspects of the interaction and dynamism. It gives priority to the method of experience and experiential learning and focuses on active participation of an individual in solving a particular problem social situation. Special importance is given not to the internalization of the set aims and values but to the models of actively changing reactions to problem social situations. In this case the aim is to find a solution that would satisfy all the participants of a constructed social situation". It increases the value of meaningfulness of studies, stimulates the student's motivation, because gained skills are related to the perception of the perspective of future social work.

Having estimated philosophical principles of problem-based learning and the aims of problem-based learning that have already been tested in medical studies it is obviously possible to state that they are also perfectly convertible to the study process of social work and the expected results.

\section{Legal determinism of social work}

Legislation plays a very important role in the construction of social work professional identity. A legal entrenchment of the profession among other professions is long-lasting, so the legal system is considered to be very clear. L. Varžinskiene (2009, p. 125) emphasizes that this results in the conventional determination of the professional jurisdiction limits and leads to a clear and mostly higher status of the profession. Legislation describes the limits of the profession and prevents any interpretations.

The professional identity of social work is defined by the laws which regulate social work practice, education and training. Since, according to L. Varžinskienè 
(2009), legal documents defining social work in Lithuania are still being developed, the identity of social work respectively features this dynamics as well. With regard to the legislative acts regulating social work, the recent legislative acts reveal attempts to strengthen social work positions by both mandatory education at a higher education level and improved professional regulation, and protection of identity. The most recent legislative act still awaiting for the approval defines social work as a professional activity which promotes social change, problem-solving related to human relationship, empowerment of people to strengthen their wellbeing, provides opportunities and assistance in improving the quality of life (The Social Work Study Field Descriptor [Draft], 2012). This definition refers to a wide spectrum of theoretical and practical knowledge and disappearing limits of the concept of social work profession. On the other hand, the Law on Social Services (2006) sets higher requirements for social work. If by the year 2006 social worker's qualification was associated with the acquired knowledge and practice, then after 2006 social worker's qualification was exclusively associated with education. By the Law on Social Services (2006), a person without social work education has no right to be a social worker; this leads to the professionalization of social work practice and a much clearer identification of the social work practice field. The identity of social work is yet more strictly formulated in The Social Work Stu$d y$ Field Descriptor ([Draft], 2012), which defines the requirements for the study programmes in the field of social work, without providing for the possibility to prepare and implement study programmes in two fields (major and minor), which would lead to the double qualification degree in the major and minor (branch) fields. According to this document, social work can be studied neither as a major nor as a minor study field (branch) in the study programmes integrating two fields. Much stricter and clearly defined requirements for social work practice and studies express attempts to construct a clear professional identity of social work.

R. Laužackas (2008) assumes that since objective professional characteristics enter education and training programmes, they determine what a person needs to learn and acquire by obtaining or upgrading their qualification. In Lithuania, there are two types of documents regulating the recognition of scientific and academic level of activities: Classifications of Areas and Fields of Science and Lists of Areas and Fields of Study at Higher Education Institutions.

The social work study field with five branches of the study field, approved in 2009 (Resolution of the Government of the Republic of Lithuania "On the Approval of the List of Areas and Fields of Study at Higher Education Institutions and the List of Qualification Degrees", 23-12-2009, No. 1749), gives grounds to presume that the level of the university studies in social work achieved over the past 20 years has been evaluated, and that a real opportunity of establishing itself not only 
in the field of studies but also science has emerged. This requires political will, because the current Order of the Minister of Education and Science of the Republic of Lithuania "On the Approval of the Fields of Science" (16-10-2012, No. V-1457) does not identify the field of social work within the area of social sciences. The old order remains in effect, yet regulated by the order approved by the Minister of Education and Science of the Republic of Lithuania on Classification of the Branches of Science (13-12-2007, No. ISAK-2420), under which various areas of social work field (Social changes, Theory of social work; Social problems and welfare, National insurance; Social care and help to handicapped) remain at the level of branches of science, and are attributed to the field of Sociology. This means that social work is recognised as a field of studies, but not as a field of science; therefore, preparation of social work researchers in Lithuania, as mentioned above in this section, has so far been impossible. This complicates the accreditation of the second-cycle studies of social work, because the requirements for the Master's degree studies state that the programme has to be managed by a professor, doctor in the field of science of social work.

The issue of recognition of social work as a science is related to the dynamics of classification of sciences in Lithuania: the classification of sciences in the country is not well established. This is evidenced by the fact that despite the fact that the most recent Order of the Minister of Education and Science of the Republic of Lithuania "On the Approval of the Fields of Science" (16-10-2012, No. V-1457) has been effective for less than a year, during the process of meta-analysis preparation, the Ministry of Education and Science organized consultations with the academic community over the changes to the classification.

However, it is very important for social work to find its scientific identity, because social work is not the same as sociology, to which field it is assigned, though social workers apply sociological methods to analyse social problems. Social work involves more than sociology which explains "what is going on?"; social work aims at addressing the question "how to handle that what is going on?".

In summary, what has so far been identified as a weakness of social work, still obstructing smooth development of social work as a profession, as assumed by B. Švedaite (2004), creates the advantage for the social work activity. Nowadays, social work is developing rapidly, supported by a growing and becoming stronger community of professionals. An important assumption is namely a lack of traditional scientific heritage and still dynamic professional identity due to dynamic and still revolutionary education policy, as well as still developing legislation regulating social work as a profession in Lithuania. Legally, the requirements for social workers' qualification growth, behind that the standards for social worker's 
education and training, seek to construct a much clearer professional identity, as well as professional status of social work.

\section{Social Work Professional Identity}

A significant development in social work professionalization in Lithuania is the formation of social work professional identity in the light of another social profession - social education. There are two positions theorizing the relation between social work and social education, constructing the professional identity of both of them. The first position focuses on the search for differences based on the reflection of human existence in the real world and the system of socio-cultural relations; the position also emphasizes different functions of social work and social education. The opposing position relates with an emphasis on similarities or convergence in the field of scientific cognition and highlights only formal separation of social work and social education professions.

The first position refers to the aim of social work, which covers not only care provision to an individual, but also an educational activity, nurturing socially significant stereotypes. In that case, according to Firsov (1996), "social work is not just a social education: social work at the same time is a social education" (cited in Leliūgienè, 2003, p. 21). This leads to both, the segregation of social practice and individual development of the knowledge sphere in social work and social education; as well as to a separate phenomenological evolution. The differences are observed in the origins of these professions. According to I. Leliūgiene (2003, p. 32), sociology is a background constructing social work. The subject of social work is linked to the one "who requests, wants something", and the object is constructed as "a person, who needs some help in his / her social life", leading to the concept client to define the object in social work activity. In that case, a social worker works with a person who has problems which interfere with his / her abilities to participate fully in social life and to live a normal life, and who is not able to handle problems independently, thus needing professional help. A social worker's activity is considered to be named as intervention, constructing a helping profession in the sphere of social security.

Meanwhile, education is a background constructing social education. A social education subject is homo educantus - a learner, in terms of I. Leliūgienè (2003, p. 21). A social educator works with a child, who has problems in his / her 
socialization process, in the education system; that leads to the concept learner to define the object in social education activity. A social educator aims to help a learner to overcome barriers of social exclusion, to provide him / her with social and educational assistance in overcoming the consequences of socio-educational educational separation (Juodaityte, 2007, p. 76). In that case, a social educator's activity is considered to be named as prevention (Leliūgienè, 2003; Leliūgienè et al., 2006).

The opposite position refers to the idea that practical areas of activity of social work and social education are closely related to each other in terms of functions, content and methods of work. The construction of social work and social education as similar professions emphasises a close cultural-historical tradition of both professions to perceive a person as the one who requires special care and attention, and leads to the application of the same concepts, such as mercy, doing good, help and others in practical activity (Leliūgienè, 2003).

A compromise position is also constructed; currently, this position is observable in Lithuania. This compromise refers to the integrity and complementarity of social work and social education: social education contributes as a recognized science, containing the object and the subject; the contribution of social work is based on valuable professional and practice activity. It is considered as a kind of cease-fire announcement, which allows focusing on the strengthening of both occupations by cooperation (Leliūgienè et al., 2006).

Nevertheless, in addition to the recognised professional significance, recently, in the process of intensive formation of social work applied research area, the positions of social work in the dichotomy of social professions have significantly strengthened. Social work is considered as gaining a much clearer identity as an autonomous profession. Meanwhile, social education is considered to survive the crisis, in terms of Juodaityte (2007), due to certain stagnation, based on non-conscious or not enough conscious evaluation of major social changes taking place in recent decades.

Internationalization as a part of social work identity plays a very important role in the process of construction of Lithuanian social work as a profession. This is related to the specific development of social work in the country. For social work education and practice development in the country, it is important to accumulate foreign experience, advancement and innovations to facilitate the professionalization of social work, as well as to draw the guidelines for the development of field research leading to the formation of social work as a science. 
Internationalization is impossible without intercultural dialogue which is one of the preconditions to successful realization of Social Work study programmes. Dialogue in study process with social workers (practices), academic staff (scientists) should have a very clear structure, the main elements of which are: cultural differences (getting to know each other, establishing the respective attitude towards each other (communication without pressure, finding a compromise), predicting interference (social, economical, legal). Intercultural communication should be useful for both sides; cultural similarities (historical past, teaching traditions, communication culture - hospitality, openness); ability to accept variety (the enduring value of the project - unique learning experience formed during the creation of the project in the context of the good experience of another country); using students' professional interests in study process and during practice of social work.

According to Dž. Baraldsnes (2012, 2012, p. 73-74), without the estimation of cultural differences there might be misunderstandings in the process of communication. This author's insight is based on the obstacles enlisted by Barna (1996), which interfere with effective intercultural communication:

Precondition of similarities. People naively expect that people of other countries are the same like them (or at least similar to them), therefore, communication should not be complicated.

Linguistic differences. When communicating in a language that is not appropriately mastered yet, people think that a word, phrase or sentence has the only one meaning - namely the meaning they intend to express.

Incorrect interpretation of body language. Incorrect interpretation of body language may often provoke conflict situations or antagonism destroying the process of communication.

Prejudice and stereotypes. Rejecting stereotypes very often prevents from making incorrect opinion about another person and helps to remain objective during communication and correctly interpret information sent by another person.

Evaluation tendencies. Different cultural values may cause negative evaluation of the representatives of another culture.

Big anxiety and stress. Intercultural communication is often related to increased anxiety and stress even in rather casual situations of intercultural communication. Stress and anxiety may increase obstacles in intercultural communication and in person's evaluation rigidity and persistent keeping to stereotypes may appear. Moreover, negative evaluation of people will dominate.

The concept of intercultural competencies becomes even more relevant under the influence of the processes of globalization. According to Z. Bauman (2007), people move even when physically they remain in the same space. Following this idea, we agree that "content of social work in recent years are becoming 
more and more global and universal in their problems and ways of their solving. Both students and teachers cannot restrict themselves only with understanding of norms and traditions of society of their country and social-political contexts, therefore, one of the essential features of future and present specialists of social work is intercultural competence that permits not only to identify universal and global social problems but also creates preconditions for the development of person's maturity" (Radzevičiene, 2014, p. 6).

Following the idea of aim of this article - changing social work in a changing society, we have to recognize that the improvement of social work identity always will be an ongoing process. Social work professionalization is a challenge to social workers, to academic community and researchers.

\section{Conclussions}

1. Over the last two decades the process of social work professionalization develops rapidly in segments of practice, studies and research.

2. Social work has moved from the stage of social services (practice) and development of social work infrastructure towards the stage of academization and scientific research. These processes highlighted the necessity for the new methods and intercultural dialog.

3. Identity of social work has established itself on the professional level and legislation level as well.

\section{References}

Bagdonas, A. (2001). Socialinis darbas Lietuvoje: raidos, praktikos ir akademinis aspektai. STEPP: Socialine teorija, empirija, politika ir praktika = Social Theory, Empirics, Policy and Practice 1: 10-35.

Baird, J. C. (1972). Issues in the Selection of Growth Goals for Social Work. Journal of Education for Social Work, Vol. 8, No. 1. Winter.

Baraldsnes, Dž. (2012). Tarptautinè ir tarpkultūriné komunikacija. Vadovèlis. Klaipėda. p. 73-74. Internet access: http://www.esparama.lt/es_parama_pletra/failai/ESFproduktai/2012_Tarptautine_ir_tarpkulturine_komunikacija.pdf [accessed 2013-08-04].

Bauman, Z. (2007). Globalizacija: pasekmès žmogui. 2-asis patais. leid. Vilnius: Apostrofa.

Čepukas, R. (2005). A Non-university Training Tendencies of Social Pedagogues and Their Evaluation in Lithuania. Doctoral dissertation. Vilnius: Vilniaus pedagoginis universitetas.

Dirgèlienè, I. (2008). Teorijos ir praktikos ryšio plètotė socialinio darbuotojo profesinejje veikloje $=$ Development of the Relationship of Theory and Practice in the Professional Activity of Social Worker. Acta Paedagogica Vilnensia. Mokslo darbai 20: 90-101.

Dirgèlienè, I., Kiaunytė, A. (2005). Supervizija Lietuvos socialinio darbo kontekste. Acta Paedagogica Vilnensia. Mokslo darbai 15: 240-254.

Dirgèlienè, I., Kiaunytè, A. (2006). Praktika rengiant socialinius darbuotojus: Klaipédos universiteto patirtis. Klaipėda: Klaipèdos universiteto leidykla. 
Dirgèlienė, I., Kiaunytė, A. (2008). Praktika rengiant socialinius darbuotojus: Klaipédos universiteto patirtis. Klaipėda: Klaipėda University Publishing House.

Epstein, L. (1999). The Culture of Social Work. Reading Foucault for Social Work (eds. A. S. Chambon, A. Irving, L. Epstein). New York: Columbia University Press, p. 3-26.

Gvaldaitė, L., Švedaitė, B. (2005). Socialinio darbo metodai. Vilnius: Socialinių darbuotojų rengimo centras.

Ivanauskienè, V., Liobikienè, N. T. (2005). Socialinio darbo studentų savirefleksijos gebejjimų ugdymas teoriniuose kursuose. Socialinis darbas. Mokslo darbai 4(1): 118-121.

Johnson, L. C. (2001). Socialinio darbo praktika. Bendrasis požiūris = Social Work Practice: A Generalist Approach. Vilnius: VU Specialiosios psichologijos laboratorija.

Jucevičienė, P. (2001). Integruotas požiūris ị socialinio darbo teoriją ir praktiką - XXI amžiaus iššūkių žmonėms atsakas. Acta Paedagogica Vilnensia 8: 189-197.

Juodaitytè, A. (2007). Socialinio gyvenimo iššūkiai ir socialinès pedagogikos teorinių, prakseologinių pozicijų kaita. Tiltai $=$ Bridges 1 (38): 75-86.

Jurkuvienè, R. (2003). Socialinio darbo mokyklos kaip socialinès novacijos Lietuvoje. Summary of Doctoral Dissertation. Kaunas: VDU Publishing.

Kavaliauskienė, V. (2005). Socialinio darbo, kaip pagalbos žmogui profesijos, raidos aspektai = Aspects of the Development of Social Work as a Helping Profession. Acta Paedagogica Vilnensia 15: 230-239.

Kavaliauskienè, V. (2010). Refleksijos kultūra - socialinio darbuotojo profesinès veiklos raiškos aspektas $=$ Reflection Culture as an Aspect of Social Worker's Professional Activity. Acta Paedagogica Vilnensia 25: 159171.

Kirikova, L., Brunevičiūtė, R., Gudaitytè, D. ir kt. (2013). Probleminio mokymosi proceso privalumai ir trūkumai: dèstytoju požiūris. Santalka: Filologija, Edukologija, T. 21, Nr. 1: 24-25.

Kozlovas, A., Malikas, L. (2004). Socialinio darbo profesinė veikla: kompetencijos ir socialinès atsakomybès ribos. Kn.: A. Bagdonas (red.). Socialinis darbas. Profesinès veiklos ivadas (tarptautinis projektas). Vilnius: VU Specialiosios psichologijos laboratorija.

Laužackas, R. (2008). Kompetencijomis grindžiamu mokymo / studijų programu kūrimas ir vertinimas. Monograph. Kaunas: Vytautas Magnus University Publishing House.

Leliūgienè, I. (2003). Socialinè pedagogika. Kaunas: Technologija.

Leliūgienė, I., Giedraitienė, E., Rupšienė, L. (2006). Socialinių darbuotojų / socialinių pedagogų rengimas Lietuvoje $=$ Training Social Workers $/$ Social Pedagogues in Lithuania. Pedagogika $=$ Pedagogics 83: 64-73.

Liobikienè, N. T. (2006). Krizių intervencija. Kaunas: Vytauto Didžiojo universitetas.

Mažeikienė, N., Lenkauskaitė, J. (2011). Probleminis mokymasis aukštojoje mokykloje. Šiauliai: Šiaulių universiteto leidykla.

Radzevičienè, L. (2014). Socialinio darbo studijų programos sociokultūtinis kontekstas. Kn.: I. Baranauskienė (sud.). Jungtinès II pakopos socialinio darbo studiju programos turinio realizavimo specifika taikant inovatyvius metodus.Vilnius: BMK leidykla.

Švedaitè, B. (2004). Socialinio darbo sistema Lietuvos visuomenès kaitos kontekstu. Acta Paedagogica Vilnensia 12: 39-49.

Šveikauskas, V., Kirikova, L. (2007). Probleminio mokymosi procesas. Mokomoji knyga. Kaunas: Kauno medicinos universitetas. Internet access: http://pm.lsmuni.lt $/ \mathrm{medziaga} / \mathrm{cd} / \mathrm{pm} / \mathrm{pm} \% 20$ procesas.pdf [accessed 2013-07-07].

Šveikauskas, V., Kirikova, L., Leonas, L. (2008). Peculiarities of Changes of Roles of Students and Lecturers in Implementation of Problem-Based Learning System. Socialiniai tyrimai: Mokslo darbai 1(11): 85-94.

Targamadze, V., Gražienè, V. (2012). Projektinio ir probleminio mokymosi(si) taikymo edukologijos studiju baigiamuosiuose darbuose rekomendacijos. Vilnius: Vilniaus universiteto leidykla, $126 \mathrm{p}$.

Vaičekauskaitè, R., Acienė, E. (2007). Moksliniu darbu rengimo metodinès rekomendacijos socialinio darbo bakalauro ir magistro programu studentams. Klaipėda: Klaipėdos universiteto leidykla.

Varžinskienė, L. (2009). The Impact of Legal Regulation on the Formation of a Status of Social Work Profession. Socialinis darbas = Social Work. Academic Papers 8 (1): 124-130.

Vareikyte, A. (2010). Socialinio darbo raida Lietuvoje. Kn.: J. R. Šinkūnienė (sud.). Socialinis darbas. Profesinė veikla, metodai ir klientai. Vilnius: Mykolo Riomerio universitetas. 


\section{ON THE DISCOURCE OF SOCIAL WORK PROFESSIONALISATION}

\section{Documents}

Studijų kokybės vertinimo centras. (2012). Socialinio darbo studiju krypties aprašas [projektas]. Vilnius.

Baltoji knyga: ES PHARE programa „Lietuvos aukštojo mokslo reforma“. (2005). Vilnius: Lietuvos švietimo ir mokslo ministerija.

The Law on Social Services of the Republic of Lithuania. 19 January 2006, No. X-493. Vilnius. Official Gazette "Valstybès žinios", 11-02-2006, No. 17-589.

Order No. ISAK-2420 of 13 December 2007 of the Minister of Education and Science of the Republic of Lithuania on Classification of the Branches of Science. Vilnius. Official Gazette "Valstybès žinios", 21-12-2007, No. $135-5513$.

Order No. V-231 of 14 February 2011 of the Minister of Education and Science of the Republic of Lithuania On the Approval of the Fields and Branches of Science. Vilnius. Official Gazette "Valstybès žinios", 24-02-2011, No. 23-1123.

Order No. V-1457 of 16 October 2012 of the Minister of Education and Science of the Republic of Lithuania On the Approval of the Fields of Science. Vilnius. Official Gazette "Valstybès žinios", 23-10-2012, No. 123-6225.

Order No. 360 of the Government of the Republic of Lithuania of 9 May 1994 On the Conception of Social Support. Vilnius. Official Gazette "Valstybès žinios", 13-05-1994, No. 36-653.

The Lithuanian Social Workers Association (1998). Code of Ethics of Social Workers in Lithuania. Vilnius. Internet access: http://www.google.lt/url?sa=t\&rct=j\&q=lietuvos\%20socialini $\% \mathrm{C} 5 \% \mathrm{~B} 3 \% 20$ darbuotoj\%C5\%B3\%20 etikos $\% 20$ kodeksas \&source $=$ web $\& \mathrm{~cd}=1 \& \mathrm{ved}=0 \mathrm{CCsQFjAA \& url=http} \% 3 \mathrm{~A} \% 2 \mathrm{~F} \% 2 \mathrm{Fwww}$.mruni. eu\%2Fmru_tt_dokumentai\%2Fkatedros\%2Fsocialinio_darbo_katedra\%2FLietuvos_socialiniu_darbuotoju_etikos_kodeksas\%2F17socialiniu_darb_etik_kod.doc\&ei=mu2iUZadGMTY0QXeqIHwCg\&usg $=$ AFQj CNHhlPRMhb6mA5pUJUJVa44gDrp8nA\&bvm=bv.47008514,d.ZWU\&cad=rja [15-05-2013].

Order No. 1749 of the Government of the Republic of Lithuania of 23 December 2009 On the Approval of the List of Areas and Fields of Study at Higher Education Institutions and the List of Qualification Degrees. Vilnius. Official Gazette "Valstybès žinios", 31-12-2009, No. 158-7135.

Order No. A1-93 of the Minister of Social Security and Labour of 5 April 2006 On the Approval of the Catalogue of Social Services. Official Gazette "Valstybès žinios", 20-04-2006, No. 43-1570.

Centre for Quality Assessment in Higher Education. (2012). The Social Work Study Field Descriptor. [Draft]. Vilnius. 
